\title{
Life Cycle Assessment dan Life Cycle Cost untuk Serat Kenaf
}

\author{
Desrina Yusi Irawati ${ }^{1}$, Melati Kurniawati ${ }^{2}$ \\ 1) Fakultas Teknik, Program Studi Teknik Industri, Universitas Katolik Darma Cendika \\ Jl. Dr. Ir. H. Soekarno 201, Surabaya, 60117 \\ 2) Fakultas Teknologi Industri, Program Studi S1 Teknik Industri, Institut Teknologi Nasional Bandung \\ Jl. PHH. Mustofa 23, Bandung, 40124 \\ E-mail: desrina.yusi@gmail.com, melati@itenas.ac.id
}

\begin{abstract}
Kenaf fiber from the kenaf plant is the excellent raw material for industry because of the various diversified products it produces. To develop sustainable kenaf fiber, information is needed on the strengths and weaknesses of kenaf cultivation systems with respect to productivity and environmental impact. Therefore, a comprehensive environmental and economic impact assessment was conducted from cultivating kenaf to kenaf fiber. The environmental impact assessment uses the Life Cycle Assessment (LCA) method and economic calculations from the life cycle of kenaf to kenaf fiber to collectors use the Life Cycle Cost (LCC) method. The calculation of environmental impacts is in accordance with the stages of ISO 14040, using a single score assessment. The LCA results show that the treatment stage is the highest contributor of the three groups of impact categories. The highest to the lowest in the impact category group that was influenced by the treatment stage were resources with a value of $21.4 \mathrm{mPt}$, human health with a value of $8.76 \mathrm{mPt}$, and ecosystem quality with a value of 1.91 $\mathrm{mPt}$. The cost identified through the $L C C$ is $R p .6,088,468,333, N V P$ and $B / C_{n e t}$ are positive. The results of the sensitivity analysis if there is a reduction in production $>6 \%$, the business is still profitable and can be run.
\end{abstract}

Keywords: Life Cycle Assessment, Life Cycle Cost, kenaf fiber

\begin{abstract}
Abstrak
Serat kenaf dari tanaman kenaf menjadi bahan baku primadona bagi industri karena berbagai produk diversifikasi yang dihasilkan. Untuk mengembangkan serat kenaf yang berkelanjutan, diperlukan informasi tentang kekuatan dan kelemahan sistem budidaya kenaf sehubungan dengan produktivitas dan dampak lingkungan. Oleh karena itu dilakukan penilaian dampak lingkungan dan ekonomi yang komprehensif dari tahap pembibitan kenaf, pemeliharaan tanaman kenaf yang meliputi pemupukan dan pemberian pestisida, pasca panen yang terdiri dari perendaman batang kenaf, penyeratan kulit batang kenaf, dan pencucian, serta tahap terakhir adalah pengiriman serat kenaf ke pengepul. Penilaian dampak lingkungan menggunakan metode Life Cycle Assessment (LCA) dan perhitungan ekonomi dari siklus hidup tanaman kenaf hingga serat kenaf sampai ke pengepul menggunakan metode Life Cycle Cost (LCC). Perhitungan dampak lingkungan sesuai dengan tahapan ISO 14040, menggunakan penilaian single score. Hasil LCA menunjukkan bahwa tahap pemeliharaan menjadi penyumbang tertinggi dari tiga kelompok kategori dampak. Urutan tertinggi sampai terendah kelompok kategori dampak yang dipengaruhi oleh tahap pemeliharaan adalah resources dengan nilai 21,4 mPt, human health senilai $8,76 \mathrm{mPt}$, dan ecosystem quality senilai $1,91 \mathrm{mPt}$. Biaya yang teridentifikasi melalui LCC sebesar Rp. 6.088.468.333, NVP dan B/Cnet bernilai positif. Hasil dari analisis sensitivitas jika terjadi pengurangan produksi $>6 \%$ maka usaha masih menguntungkan dan dapat dijalankan.
\end{abstract}

Kata kunci: Life Cycle Assessment, Life Cycle Cost, serat kenaf 


\section{Pendahuluan}

Dewasa ini industri manufaktur melibatkan bahan mentah, konsumsi energi dan air, serta proses pembuangan limbah ke lingkungan dalam jumlah besar (Ahmad et al., 2019). Jika kondisi tersebut terus berlangsung maka pencemaran lingkungan akan terus terjadi. Terdapat sebuah konsep untuk melakukan perbaikan lingkungan yaitu green supply chain. Konsep green supply chain mengintegrasikan sustainable environmental processes ke dalam traditional supply chain yang artinya perusahaan melakukan serangkaian kegiatan industri dari hulu sampai hilir dengan memperhatikan aspek lingkungan. Ketersediaan bahan baku merupakan bagian hulu dari industri.

Serat kenaf menjadi serat alami terpenting di dunia (Santoso et al., 2015). Hampir semua bagian kenaf dapat digunakan untuk bahan baku berbagai industri, namun yang menjadi andalan adalah serat dari batangnya. Serat kenaf mendapat perhatian kalangan industri dalam 10 tahun terakhir karena berbagai produk diversifikasi yang dihasilkan serat kenaf. Produk diversifikasi serat kenaf adalah bahan baku tekstil (Indriani et al., 2013), produk fashion (Masykur \& Puspitasari, 2019), kertas lainer (Kardiansyah \& Sugesty, 2014; Tahir et al., 2011), industri otomotif (Hassan et al., 2017), konstruksi (Akil et al., 2015), dan lain-lain. Beberapa keunggulan serat kenaf terdapat pada hal biaya, kepadatan, keterbaruan, daur ulang, abrasivitas dan biodegradasi (Jeyanthi \& Rani, 2012). Hal tersebut menunjukkan bahwa dari segi ekonomi, kenaf memiliki prospek dan peluang cerah di masa depan (Sudjindro, 2012).

Persebaran kenaf terbesar di Indonesia ada di lahan bonorowo, Laren, Lamongan. Lahan bonorowo adalah lahan menjadi rawa ketika musim hujan. Budidaya kenaf di lahan bonorowo menguntungkan proses budidaya kenaf pada tahap perendaman serat kenaf. Namun sebenarnya lahan bonorowo merupakan lahan yang kurang potensial untuk tanaman karena $\mathrm{pH}$ tanah dan kandungan hara rendah, kandungan $\mathrm{Fe}$ dan alumunium tinggi, dan genangan air terkadang susah dikendalikan (Purnomo et al., 2005). Kebutuhan nutrisi suatu tanaman tergantung pada kondisi iklim dan sifat-sifat tanah. Kenaf salah satu tanaman yang membutuhkan nutrisi tambahan berupa pupuk untuk meningkatkan produksi dan kualitas serat (Mohd et al., 2014). Kelembaban dan curah hujan yang tinggi selama musim tanam dapat menyebabkan penyakit jamur pada tanaman kenaf. Penyakit dan hama ini dapat merusak tunas muda, kuncup bunga. dan buah kenaf yang sedang berkembang. Oleh sebab itu penggunaan pestisida sangat penting untuk perlindungan kenaf (Aminah et al., 2006).

Penggunaan pupuk kimia dan pestisida secara terus menerus berbahaya bagi ekosistem lingkungan. Padang rumput yang menerima nitrogen $(\mathrm{N})$ dalam bentuk urea, maka urea di tanah dihidrolisis dengan cepat menjadi ion amonium (NH4+). Bagian tersebut selanjutnya berubah sebagai dinitrogen oksida (N2O), merupakan penyumbang gas rumah kaca (Singh et al., 2013). Penggunaan pupuk juga berkontribusi pada pengasaman tanah, eutrofikasi air permukaan, polusi akuifer, dan peningkatan emisi amonia ( $\mathrm{NH} 3$ ) ( $\mathrm{Li}$ et al., 2014). Aplikasi pestisida telah mengakibatkan kontaminasi ekosistem tanah (Imfeld, 2012). Selain itu, kendala utama produksi serat kenaf terdapat saat pasca panen, yaitu biaya tenaga kerja yang tinggi terutama saat masa tebang, angkut, penyeratan (retting), serta bau menyengat dari air rendaman kenaf. Untuk mengembangkan hasil serat kenaf yang lebih berkelanjutan, diperlukan informasi tentang kekuatan dan kelemahan sistem budidaya sehubungan dengan produktivitas dan dampak lingkungan. Oleh karena itu, diperlukan penilaian dampak lingkungan dan ekonomi yang komprehensif dari sistem pertumbuhan kenaf sampai dihasilkan serat kenaf.

Penilaian dampak lingkungan yang terkait dengan pertumbuhan kenaf dapat menggunakan metode Life Cycle Assessment (LCA). LCA adalah metodologi standar ISO yang umum diterapkan untuk menilai kategori dampak lingkungan pada siklus hidup produk dari penggunaan dan pengolahan bahan (Perez Gil et al., 2013). LCA sering digunakan dalam industri sebagai alat untuk mengukur dampak dari opsi produksi yang dijalankan. Salah satunya LCA digunakan untuk menentukan dampak lingkungan dari produksi pertanian (Tuomisto et al., 2012; Nemecek et al., 2011; Jonell et al., 2015). Manfaat metode LCA adalah mengembangkan evaluasi sistematis dari konsekuensi lingkungan terkait dengan proses suatu produk (Tukker, A., 2000), menganalisis trade-off lingkungan 
terkait dengan satu atau lebih produk atau proses untuk membantu mendapatkan masukan terhadap tindakan yang direncanakan (Vink et al., 2003), mengukur siklus kehidupan atau proses yang berkontribusi utama menghasilkan dampak lingkungan ke udara, air, dan tanah (Miettinen \& Hamalainen, 1997; Fernando et al., 2015), menilai dampak manusia dan ekologis dari konsumsi material dan pelepasan lingkungan dalam komunitas lokal, wilayah, dan dunia (Frankl \& Rubik, 1999), membandingkan dan mengidentifikasi dampak kesehatan serta ekologis antara dua atau lebih produk atau proses tertentu dan area lingkungan spesifik yang menjadi perhatian. Informasi LCA dapat digunakan dengan faktor-faktor lain, seperti data biaya dalam mempertimbangkan pemilihan suatu produk atau proses (Daddi et al., 2017). Penelitian LCA tentang budidaya kenaf di Indonesia pernah dilakukan oleh Irawati \& Wulandari (2019). Perbedaan antara penelitian ini dengan penelitian sebelumnya adalah pada penelitian sebelumnya hanya mengukur dampak lingkungan dari perkebunan kenaf menggunakan metode LCA. Penilaian dampak yang diukur adalah empat kelompok kategori dampak yang dihasilkan dari penilaian Impact 2002+. Selain itu data dihitung secara keseluruhan tanpa dikelompokkan sesuai siklus serat kenaf. Data yang digunakan pada penelitian sebelumnya adalah data ketika perkebunan kenaf berjalan mendekati ideal. Pada penelitian ini selain mengukur dampak lingkungan menggunakan LCA, juga dilakukan penilaian ekonomi dengan LCC. Pada tahap LCA, data yang diolah dikelompokkan berdasarkan siklus serat kenaf sampai serat kenaf dikirim ke pengepul. Penilaian dampak berdasarkan Eco Indicator 99 dan data yang digunakan adalah data saat kondisi budidaya kenaf tidak sesuai harapan akibat cuaca ekstrem.

Menurut Meiriza et al. (2017), metode LCC merupakan pendekatan yang menghasilkan total biaya dengan mempertimbangkan variabel biaya pemeliharaan, biaya operasional, biaya pergudangan, biaya populasi dan biaya pembelian. LCC berguna untuk mengambil keputusan berdasarkan nilai ekonomis dengan mempertimbangkan aspek yang berhubungan dengan proses produksi selama jangka waktu umur hidup produk tersebut (Buyung et al., 2019; Sugirianta et al.,
2016). LCC telah digunakan di berbagai subjek penelitian seperti dampak energi alternatif (Benedict, 2017; Petrillo et al., 2016), produksi makanan (Ahmad et al., 2019), perbaikan proses produksi (Dian et al., 2014), proyek pembangunan (Buyung et al., 2019), maupun proyek pengadaan mesin (Meiriza et al., 2017). Menurut Buyung et al. (2019) metode LCC memiliki banyak variabel yang tak terduga, salah satu cara untuk memperkirakan adalah meninjau ke belakang dan memperkirakan hasil ke masa yang akan datang (forecast). Pada penelitian ini LCC digunakan untuk mengidentifikasi biaya yang melekat pada budidaya tanaman kenaf sampai menjadi serat kenaf di lahan bonorowo Laren, Lamongan. Setelah dilakukan identifikasi biaya dari setiap proses kemudian dilakukan analisis sensitivitas.

Penelitian ini merupakan langkah awal menuju green dengan melakukan penilaian dampak lingkungan dan ekonomi dari siklus hidup produksi tanaman kenaf menjadi serat kenaf dengan menggunakan metode LCA dan LCC. Siklus hidup tersebut meliputi tahap pembibitan kenaf, pemeliharaan tanaman kenaf yang meliputi pemupukan dan pemberian pestisida, pasca panen yang terdiri dari perendaman batang kenaf, penyeratan kulit batang kenaf, dan pencucian, dan tahap terakhir adalah pengiriman serat kenaf ke pengepul. Informasi yang diperoleh dalam penelitian ini berguna membuat kebijakan untuk menyeimbangkan produksi serat kenaf sebagai raw material yang berkelanjutan.

\section{Metodologi}

Penilaian dampak lingkungan dan ekonomi dari siklus hidup produksi tanaman kenaf menjadi serat kenaf menggunakan metode LCA dan LCC. Model penilaian kinerja lingkungan dan ekonomi dijelaskan secara singkat di bagian flowchart berikut ini.

\section{Pengumpulan Data}

Data yang digunakan pada penelitian ini merupakan data hasil wawancara dengan ketua kelompok tani kenaf, Laren, Lamongan. Data yang dikumpulkan mulai dari data tahap pembibitan kenaf, pemeliharaan tanaman kenaf yang meliputi pemupukan dan pemberian pestisida, pasca panen yang terdiri dari perendaman batang kenaf, penyeratan kulit batang kenaf, dan pencucian, dan tahap 
terakhir adalah pengiriman serat kenaf ke pengepul. Dalam siklus tersebut berisikan data tentang jumlah, jenis dan harga bahan atau alat pertumbuhan kenaf, transportasi, jumlah panen, dan harga jual serat kenaf.

\section{Research Question}

Bagaimana dampak lingkungan dan besar biaya selama proses pertumbuhan tanaman kenaf sampai panen serat kenaf, dan serat kenaf dikirim ke pengepul di lahan bonorowo Laren

\section{Tahap Pengumpulan Referensi}

Konsep pertumbuhan tanaman kenaf di lahan bonorowo Laren, LCA, dan LCC

\section{Tahap Pengumpulan Data}

Data diperoleh dari hasil wawancara dengan ketua kelompok tani kenaf Laren, Lamongan.

Data yang dikumpulkan: jumlah, jenis dan harga bahan/alat selama budidaya kenaf sampai serat kenaf terkumpul di pengepul, transportasi, jumlah panen, dan harga jual serat kenaf.

\section{Tahap Pengolahan Data}

Analisis dampak lingkungan menggunakan LCA: Goal \& scope definition, Life Cycle Inventory, Life Cycle Impact Assessment, dan Interpretation

Analisis biaya menggunakan LCC: Biaya investasi, Biaya Operasional, Net Present Value (NPV), Net

Benefit Cost $\left(\mathrm{B} / \mathrm{C}_{n e t}\right)$, dan analisis sensitivitas

\begin{tabular}{c|}
\hline \\
Analisis terhadap hasil pengolahan LCA dan LCC \\
$\qquad$ \\
$\underline{\text { Tahap Analisis }}$ \\
\hline
\end{tabular}

Gambar 1. Alur penelitian

\section{Model LCA}

Ruang lingkup tahap LCA pada penelitian ini adalah cradle to gate, yang mencakup semua proses hulu di produksi serat kenaf. Langkah pengerjaan LCA berdasarkan metodologi ISO 14010 yang terdiri dari empat fase yaitu:

1. Goal and scope definition

Tujuan umum LCA pada sistem pertumbuhan kenaf adalah menentukan dampak lingkungan dari siklus pertumbuhan kenaf di lahan bonorowo Laren dan mengidentifikasi sumber penyebab dampak lingkungan terbesar dari siklus tersebut. Ruang lingkup siklus hidup pertumbuhan kenaf sampai menjadi serat kenaf pada penelitian ini meliputi tahap pembibitan kenaf, pemeliharaan tanaman kenaf yang meliputi pemupukan dan pemberian pestisida, pasca panen yang terdiri dari perendaman batang kenaf, penyeratan kulit batang kenaf, dan pencucian, dan tahap terakhir adalah pengiriman serat kenaf ke pengepul. Unit fungsional yang digunakan pada penelitian ini adalah $1 \mathrm{~kg}$ serat kenaf. Obyek yang dituju adalah kelompok tani lahan bonorowo Laren.

2. Life Cycle Inventory (LCl)

Langkah kedua LCA ini adalah mengelompokkan dan mengompilasi input dan output dari masing-masing tahapan yang menjadi ruang lingkup penelitian. Data input dan output diperoleh dari informasi ketua kelompok tani lahan bonorowo, Laren. Data input dan output disesuaikan dengan ecoinvent database yang telah tersedia di SimaPro.

3. Life Cycle Impact Assessment (LCIA)

Pada tahap LCIA adalah mengonversi data input dan output dari $\mathrm{LCl}$ sehingga menghasilkan dampak lingkungan pada masing-masing siklus dan bagian penyebab dari dampak tersebut. Pengolahan data menggunakan software SimaPro 9 mengikuti pedoman yang ditetapkan dalam standar ISO 14040. Metode LCIA yang dipilih pada pengolahan dengan SimaPro 9 adalah Eco Indictor 99. Indikator dampak yang diukur dari Eco Indicator 99 adalah carcinogens, respiratory organics, respiratory inorganics, climate change, radiation, ozone layer, ecotoxity, acidification/ euthrophication, land use, minerals, dan fossil fuel. Kesebelas kategori dampak dikelompokkan menjadi tiga kategori dampak yaitu kesehatan manusia, kualitas ekosistem dan sumber daya (Goedkoop, M. \& Spriensma, R., 2000) .

\section{Interpretation}

Ini adalah tahap pembahasan hasil dari tahap sebelumnya dalam kaitannya dengan tujuan penelitian.

\section{Model LCC}

Pada tahap perhitungan biaya menggunakan metode LCC maka semua biaya 
yang dikeluarkan selama proses penanaman kenaf sampai menjadi serat kenaf diperhitungkan.

$$
\text { LCC = Biaya investasi + Biaya Opersional }
$$

Pers. 1

Data yang dihitung terdiri dari biaya investasi, biaya operasional, biaya pemeliharaan, biaya populasi dan biaya yang harus dikurangi (Meiriza et al., 2017).

Biaya investasi awal adalah biaya yang harus dikeluarkan dalam pembangunan sebuah proyek (Utari et al., 2016). Dalam penelitian ini meliputi sewa lahan, pembelian bibit dan pembelian peralatan. Biaya operasional merupakan biaya yang dikeluarkan selama proses produksi berlangsung (Meiriza et al., 2017). Biaya operasional terdiri dari biaya tanaman sebelum menghasilkan dan biaya setelah menghasilkan. Biaya pemeliharaan masuk ke dalam biaya tanam sebelum menghasilkan, yang terdiri dari biaya pupuk dan biaya penyemprotan pestisida.

Pendapatan yang didapatkan petani selama masa hidup kenaf menjadi serat kenaf dihitung dengan mencari selisih antara penerimaan dengan semua biaya yang melekat pada produk tersebut. Penerimaan diperoleh dari perkalian total produksi yang terjual dengan harga jual (Sutjipta, 2006).

$$
\mathrm{TR}=\mathrm{Y} \times \mathrm{Py}
$$

Pers.2

Sebagai keterangan, $\mathrm{TR}=$ total revenue, $\mathrm{Y}=$ jumlah produksi yang dihasilkan, $P y=$ harga per produk.

Untuk mengetahui keuangan bersih dan nilai manfaat dari sebuah usaha maka dilakukan perhitungan Net Present Value (NPV) dan Net Benefit/Cost. Persamaan yang digunakan untuk menghitung NPV dan $\mathrm{B} / \mathrm{C}_{n e t}$ adalah sebagai berikut (Utari et al., 2016):

$$
\begin{aligned}
& \mathrm{NPV}=\sum_{i=1}^{n} N B_{\mathrm{i}}(1+\mathrm{i})^{-n} \\
& \mathrm{~B} / \mathrm{C}_{\mathrm{net}}=\frac{\sum_{i=1}^{n} \overline{N B}(+)}{\sum_{i=1}^{n} \overline{B N}(-)}
\end{aligned}
$$

Pers. 3

Pers. 4

Sebagai keterangan, BT $=$ Net Benefit, $i=$ discount factor, $\mathrm{n}=$ Tahun. Jika, NPV; $\mathrm{B} / \mathrm{C}_{\text {net }}<$ 0 , maka usaha tidak layak untuk dijalankan.
$\mathrm{NPV} ; \mathrm{B} / \mathrm{C}_{\text {net }}=0$, maka usaha berada dalam kondisi total revenue $=$ total cost. $\mathrm{NPV} ; \mathrm{B} / \mathrm{C}_{\text {net }}>$ 0 , maka usaha tani layak untuk dijalankan.

Selanjutnya dilakukan analisis sensitivitas untuk mengetahui sampai di mana usaha akan tetap layak jika dilakukan penurunan produksi. Analisis sensitivitas diasumsikan dari data masa lalu yaitu penurunan produksi sebesar $6 \%$.

\section{Hasil dan Diskusi}

Evaluasi lingkungan dan ekonomi pada tanaman kenaf sampai diperoleh serat kenaf dilakukan dari perspektif siklus hidup, menggunakan LCA dan LCC. Model penilaian kinerja lingkungan dan ekonomi dijelaskan secara singkat di bagian berikut.

\section{Potensi Lahan Bonorowo Laren}

Berdasarkan permintaan pasar dunia untuk serat alam yang ramah lingkungan, maka negara-negara berkembang seperti Indonesia, Vietnam, Malaysia, Filipina, Thailand, Bangladesh, dan India mempunyai peluang besar menjadi negara produsen serat kenaf karena negara-negara tersebut memiliki sumber daya alam yang mendukung. Tingginya minat konsumen terhadap serat kenaf maka perlu disiapkan dan dikembangkan teknik penanaman dan daerah pengembangan.

Pengembangan tanaman kenaf di Indonesia dilakukan di lahan bonorowo, lahan gambut, dan lahan podsolik merah kuning. Setiap jenis lahan yang digunakan memiliki sifat tersendiri sehingga teknik budidaya sedikit berlainan. Umumnya proses pertumbuhan kenaf sampai menghasilkan serat kenaf adalah pengolahan tanah, penyebaran bibit, pengairan, pemupukan, penyiangan gulma, pengendalian hama, panen, perendaman, penyeratan, dan penjemuran. Lahan bonorowo merupakan lahan dengan banjir musiman. Lahan ini dijumpai di wilayah Jawa Timur dan Jawa Tengah, salah satu wilayah Jawa Timur adalah di kawasan Lamongan tepatnya desa Laren. Lahan bonorowo Laren merupakan lahan penanaman kenaf terbesar di Indonesia. Saat terendam banjir, lahan bonorowo Laren tidak dapat dimanfaatkan oleh tanaman pangan, kecuali bertanam tanaman kenaf. Hal ini dikarenakan batang kenaf akan tumbuh akar adventif jika batang terendam air. Waktu tanam kenaf terbaik dilakukan pada bulan 
September-Oktober. Pada lahan bonorowo khususnya lahan bonorowo Laren, pengairan dilakukan dengan mengambil air sungai Bengawan Solo, namun pengairan dilakukan jika musim panas terlalu ekstrem. Keunggulan penanaman kenaf di lahan bonorowo adalah perendaman batang kenaf langsung dilakukan pada lahan bonorowo yang banjir, tidak membutuhkan kolam khusus.

Lahan podsolik merah kuning yang dijadikan lahan pengembangan kenaf berada di Kalimantan Selatan dan Timur, waktu tanam pada bulan Februari-Maret. Lahan ini memiliki $\mathrm{pH}$ rendah, konsentrasi Fe dan Al yang tinggi serta peka terhadap erosi. Tingginya kandungan Al membuat kecambah kenaf mengalami keracunan sehingga pertumbuhan kenaf terhambat (Heliyanto et al., 1998; Marjani et al., 2009). Penanaman kenaf di lahan gambut berada di wilayah Kalimantan Barat, waktu tanam terbaik pada bulan MaretApril (Kangiden et al., 1996). Ciri-ciri lahan gambut adalah kaya akan bahan organik, unsur mikro ( $\mathrm{Zn}, \mathrm{Cu}$, dan $\mathrm{Mn})$, tetapi $\mathrm{pH}$ tanah rendah dan sering terjadi genangan air karena pasang dan surut air laut. Perilaku pasang surut itu sulit dikendalikan (Sastrosupadi \& Santoso, 2002). Pada lahan podsolik merah kuning dan gambut terdapat penambahan langkah pengerjaan yaitu pengapuran tanah. Hal ini bertujuan menormalkan nilai $\mathrm{pH}$ tanah. Di samping itu perendaman batang kenaf dilakukan pada kolam perendaman yang telah disiapkan (Santoso, B., 2014).

\section{Life Cycle Inventory (LCI)}

Serat kenaf merupakan jenis serat sel berdinding tebal berlignin, berfungsi sebagai penahan terhadap tegangan. Keunggulan ini memberikan manfaat sebagai bahan baku industri dan bagi perekonomian warga Laren. Berdasarkan informasi dari ketua kelompok tani Laren, serat kenaf hasil budidaya warga Laren menjadi komoditas ekspor bahan mentah dalam pembuatan dashboard dan interior otomotif. Proses bertanam kenaf di lahan bonorowo Laren sampai menghasilkan serat kenaf melalui tahap pemilihan benih yang bermutu, penyebaran benih, pemupukan, pemeliharaan, panen, perendaman, penyeratan, pengeringan, dan pengangkutan.

Penanaman kenaf di lahan bonorowo Laren dimulai pada bulan September sampai Februari. Dalam penelitian ini, data yang digunakan berdasarkan tanam kenaf bulan September 2019 sampai Maret 2020 ketika serat kenaf telah kering dan siap didistribusikan ke pengepul. Total lahan bonorowo yang dimanfaatkan untuk budidaya kenaf pada tahun 2019-2020 adalah $393 \mathrm{Ha}$.

\section{Life Cycle Impact Assessment (LCIA)}

Serat kenaf yang dihasilkan dari $393 \mathrm{Ha}$ lahan bonorowo Laren adalah $117.900 \mathrm{~kg}$. Berdasarkan proses tanaman kenaf menjadi $117.900 \mathrm{~kg}$ serat kenaf, dibutuhkan bahanbahan yaitu benih kenaf sebanyak $4.930 \mathrm{~kg}$, pupuk urea $128.000 \mathrm{~kg}$, pestisida $10,5 \mathrm{~kg}$. Proses pengiriman serat kenaf dari petani ke pengepul menggunakan truk. Konsumsi solar pada proses pengiriman tersebut adalah 1.700 $\mathrm{kg}$. Seluruh data bahan serta hasil serat kenaf dikelompokkan sesuai siklusnya, selanjutnya diolah menggunakan SimaPro 9, metode Eco Indicator 99. Data yang diolah disesuaikan dengan ecoinvent database yang tersedia pada software SimaPro. Data input dan output secara lengkap disajikan seperti Gambar 2.

\begin{tabular}{|c|c|c|c|c|c|c|c|c|}
\hline Outputs to technosphere: Products and co-products & Amount & Unit & Quantity & Allocation & Waste type & \multirow{2}{*}{\multicolumn{2}{|c|}{$\begin{array}{l}\text { Category } \\
\text { Agricultural }\end{array}$}} & Comment \\
\hline Serat Kenaf All & 1179000 & $\mathrm{~kg}$ & Mass & $100 \%$ & not defined & & & \\
\hline \multicolumn{9}{|l|}{ Add } \\
\hline \multicolumn{2}{|l|}{ Outputs to technosphere: Avoided products } & \multirow[t]{2}{*}{ Unit } & \multirow[t]{2}{*}{ Distribution } & \multirow[t]{2}{*}{ SD2 or 2SD } & \multirow[t]{2}{*}{ Min } & \multirow[t]{2}{*}{$\operatorname{Max}$} & \multirow[t]{2}{*}{ Comment } & \\
\hline Add & & & & & & & & \\
\hline & & & \multicolumn{5}{|l|}{ Inputs } & \\
\hline \multirow[t]{2}{*}{ Inputs from nature } & \multirow[t]{3}{*}{ Sub-compartmer } & \multirow[t]{2}{*}{ Unit } & \multirow[t]{2}{*}{ Distribution } & \multirow[t]{2}{*}{ SD2 or $2 S D$} & \multirow[t]{2}{*}{ Min } & \multirow[t]{2}{*}{ Max } & \multirow[t]{2}{*}{ Comment } & \\
\hline & & & & & & & & \\
\hline Inputs from technosphere: materials/fuels & & Unit & Distribution & SD2 or 2SD & Min & $\operatorname{Max}$ & Comment & \\
\hline Pembibitan & 1 & $\mathrm{~kg}$ & Undefined & & & & & \\
\hline Pemeliharaan & 1 & $\mathrm{~kg}$ & Undefined & & & & & \\
\hline Pasca panen & 1 & $\mathrm{~kg}$ & Undefined & & & & & \\
\hline \multicolumn{2}{|l|}{ Transportasi } & $\mathrm{kg}$ & Undefined & & & & & \\
\hline
\end{tabular}

Gambar 2. Input data di SimaPro 
Eco Indicator 99 adalah pendekatan endpoint yang dilanjutkan dengan identifikasi area yang menjadi pusat perhatian yaitu kategori kerusakan hingga penentuan penyebab kerusakan. Metode Eco Indicator 99 terdiri dari sebelas indikator dampak yang kesebelas indikator tersebut merupakan bagian dari tiga kategori kerusakan yaitu kesehatan manusia, kualitas ekosistem dan sumber daya. Kategori kerusakan kesehatan manusia adalah kategori utama yang berkontribusi $89 \%$ terhadap hasil kerusakan yang diperoleh Eco Indicator 99 (Dreyer et al., 2003). Hal tersebut menjadi alasan dipilihnya metode Eco Indicator 99 karena pertumbuhan tanaman kenaf sampai menjadi serat kenaf yang di kirim ke pengepul masih berjalan secara manual, penggunaan tenaga manusia sangat besar.

Penentuan dampak lingkungan pada tahap LCIA diperoleh dari hasil olah data tahap LCI. Pada tahap LCIA, pembobotan sebelas dampak lingkungan mengikuti langkah single score. Analisis single score adalah langkah opsional dalam analisis siklus hidup sesuai dengan pedoman ISO 14044. Analisis single score merupakan pembobotan (kuantitatif) yang mewakili kepentingan relatif dari dampak lingkungan yang berbeda dan digunakan untuk menghitung satu nilai gabungan (skor tunggal). Analisis single score digunakan untuk mendukung pengambilan keputusan, terutama pada saat itu sulit untuk memiliki kesimpulan keseluruhan hanya berdasarkan hasil titik tengah (Heijungs et al., 2007).

Berdasarkan hasil penilaian dampak siklus pertanian kenaf menggunakan pembobotan single score per kategori dampak lingkungan pada Tabel 1, diketahui bahwa siklus penyumbang terbesar kategori dampak lingkungan adalah tahap pemeliharaan. Tahap pemeliharaan memiliki nilai dampak paling tinggi pada kategori carcinogens, respiratory organics, respiratory inorganics, climate change, radiation, ozone layer, ecotoxity, acidification/ euthrophication, minerals, dan fossil fuel. Tahap pembibitan mempunyai nilai dampak paling tinggi pada kategori dampak land use. Tahap pasca panen tidak berpengaruh pada dampak lingkungan dikarenakan pada tahap pasca panen menggunakan air untuk proses perendaman, penyeratan, dan pencucian.

Berdasarkan penilaian dampak single score per tiga kelompok kategori dampak pada Tabel 2 dan Gambar 3, diketahui bahwa tahap pemeliharaan menjadi penyumbang tertinggi dari ketiga kelompok kategori dampak. Urutan tertinggi sampai terendah kelompok kategori dampak yang dipengaruhi oleh tahap pemeliharaan adalah yang pertama resources dengan nilai $21,4 \mathrm{mPt}$, kedua human health senilai $8,76 \mathrm{mPt}$, dan ketiga ecosystem quality senilai 1,91 mPt. Kelompok kategori sumber daya terdiri dari kategori dampak minerals dan fossil fuels. Tahap pemeliharaan berpengaruh terhadap fossil fuels dan minerals, yaitu sebesar 20,9 mPt dan 0,464 mPt. Kelompok kategori kesehatan manusia terdiri dari kategori dampak carcinogens, respiratory organics, respiratory inorganics, climate change, radiation, dan ozone layer. Tahap pemeliharaan berpengaruh besar pada dampak respiratory inorganic senilai $6,31 \mathrm{mPt}$, selanjutnya climate change senilai $1,99 \mathrm{mPt}$, carcinogens senilai $0,435 \mathrm{mPt}$, radiation senilai $0,0185 \mathrm{mPt}$, ozone layer senilai $0,00134 \mathrm{mPt}$, dan respiratory organic senilai $0,0051 \mathrm{mPt}$.

Tabel 1. Hasil single score per kategori dampak lingkungan

\begin{tabular}{|l|c|c|c|c|c|}
\hline & Unit & Total & Pembibitan & Pemeliharaan & Transportasi \\
\hline Total & $\mathrm{mPt}$ & 33,8 & 0,526 & 32 & 1,22 \\
\hline Carcinogens & $\mathrm{mPt}$ & 0,465 & 0,0146 & 0,435 & 0,0149 \\
\hline Respiratory organic & $\mathrm{mPt}$ & 0,00587 & 0,0000291 & 0,0051 & 0,000736 \\
\hline Respiratory inorganics & $\mathrm{mPt}$ & 6,66 & 0,038 & 6,31 & 0,308 \\
\hline Climate change & $\mathrm{mPt}$ & 2,08 & 0,00798 & 1,99 & 0,0808 \\
\hline Radiation & $\mathrm{mPt}$ & 0,0203 & 0,0000579 & 0,0185 & 0,0018 \\
\hline Ozone layer & $\mathrm{mPt}$ & 0,0014 & 0,00000261 & 0,00134 & 0,0000607 \\
\hline Ecotoxicity & $\mathrm{mPt}$ & 0,964 & 0,00278 & 0,932 & 0,0292 \\
\hline Acidification/Eutrophication & $\mathrm{mPt}$ & 0,734 & 0,00636 & 0,699 & 0,0293 \\
\hline Land use & $\mathrm{mPt}$ & 0,733 & 0,42 & 0,278 & 0,0349 \\
\hline Minerals & $\mathrm{mPt}$ & 0,486 & 0,00192 & 0,464 & 0,0201 \\
\hline Fossil fuels & $\mathrm{mPt}$ & 21,6 & 0,034 & 20,9 & 0,702 \\
\hline
\end{tabular}


Tabel 2. Hasil single score pada tiga kelompok kategori dampak lingkungan

\begin{tabular}{|l|c|c|c|c|c|}
\hline & Unit & Total & Pembibitan & Pemeliharaan & Transportasi \\
\hline Total & $\mathrm{mPt}$ & 33,8 & 0,526 & 32 & 1,22 \\
\hline Resources & $\mathrm{mPt}$ & 22,1 & 0,036 & 21,4 & 0,722 \\
\hline Human Health & $\mathrm{mPt}$ & 9,23 & 0,0606 & 8,76 & 0,407 \\
\hline Ecosystem Quality & $\mathrm{mPt}$ & 2,43 & 0,429 & 1,91 & 0,0934 \\
\hline
\end{tabular}

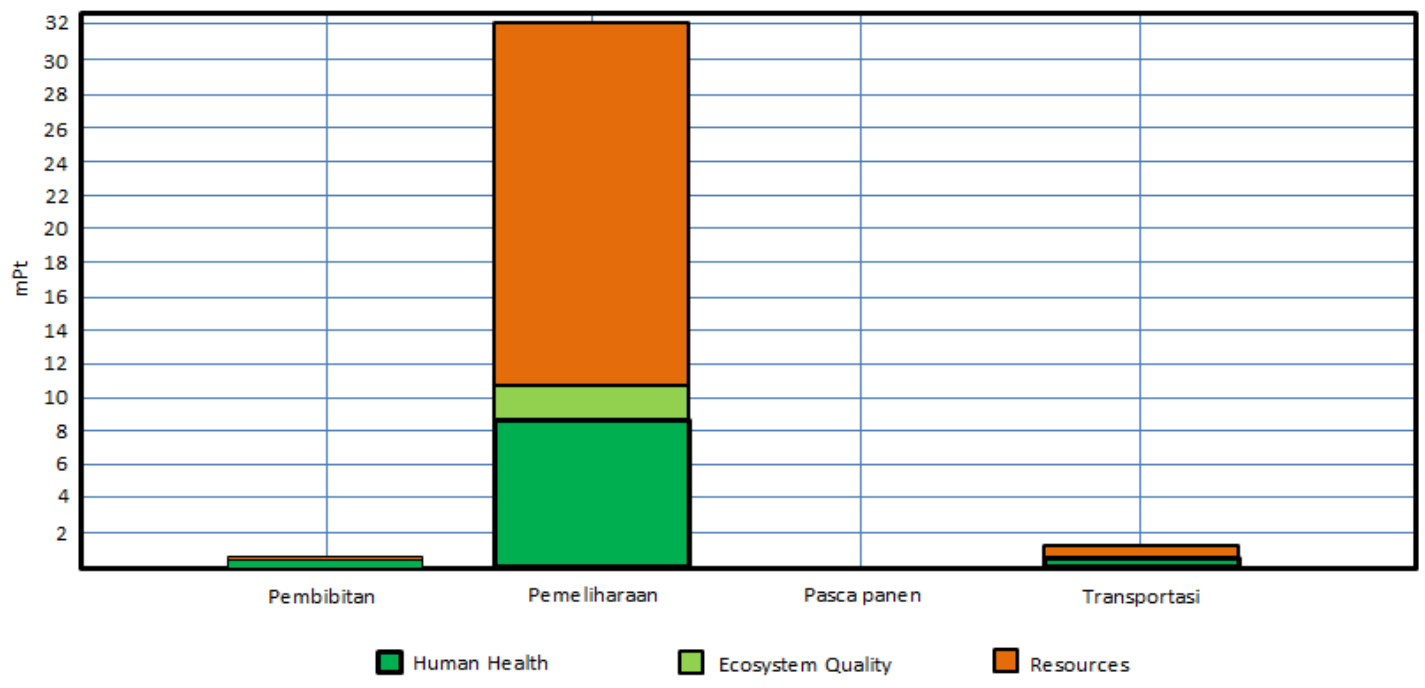

Method: Eco-indicator 99 (H) V2.07 / Europe El $99 \mathrm{H} / \mathrm{A} /$ Single score

Gambar 3. Grafik hasil single score pada tiga kategori dampak lingkungan

Sedangkan kelompok kategori dampak kualitas ekosistem tediri dari kategori dampak ecoxitocity, acidification, dan land use. Tahap pemeliharaan berpengaruh besar terhadap kategori dampak ecoxitocity senilai $0,932 \mathrm{mPt}$ dan dampak acidification senilai $0,699 \mathrm{mPt}$, sedangkan tahap pemeliharaan tidak mempengaruhi dampak land use. Dampak land use dipengaruhi oleh tahap pembibitan.

Tingginya nilai dampak kategori akibat tahap pemeliharaan dikarenakan pada tahap pemeliharaan menggunakan bahan kimia yaitu urea dan pestisida. Dalam prosesnya pupuk urea membutuhkan energi. Energi yang digunakan dalam proses produksi dan transportasi. Energi ini berpengaruh pada ketersediaan bahan bakar fosil. Penggunaan urea dapat mempengaruhi sistem pernapasan karena pada urea mengandung nitrogen oxides, ammonia, sulfur dioxide, dan sulfate dengan ukuran $<2,5$ um. Hal ini mudah terhirup oleh manusia dan mengiritasi sistem pernapasan (Kunzli et al., 2010). Penguapan pupuk menghasilkan emisi $\mathrm{CxHy}$ dan NOx yang menyebabkan gas rumah kaca, salah satu penyebab tidak langsung terjadinya perubahan iklim (Wang et al., 2017).

\section{Life Cycle Cost (LCC)}

Life cycle Cost (LCC) pada penelitian ini digunakan untuk mengidentifikasi biaya-biaya yang melekat dari proses awal hingga distribusi serat kenaf di lahan bonorowo. Proses identifikasi dibagi menjadi dua tahap yaitu proses identifikasi biaya investasi dan dilanjutkan dengan proses identifikasi biaya operasional. Selanjutnya biaya ini digunakan untuk menentukan studi kelayakan budidaya kenaf sampai menghasilkan serat kenaf di lahan bonorowo Laren.

\section{Biaya Investasi}

Lahan yang digunakan dalam budidaya kenaf merupakan hasil sewa lahan, sehingga petani kenaf tidak melakukan pembukaan lahan. Penyewaan lahan dilakukan selama satu siklus penanaman. Biaya sewa lahan per hektar adalah Rp. 2.000.000. Biaya lain yang masuk dalam biaya investasi awal adalah pembelian peralatan. Peralatan yang digunakan antara lain cangkul, timba, ember, sarung tangan, serta depresiasi alat penyemprot pestisida dan masker. Selain itu, dibutuhkan bibit untuk penanaman dengan harga bibit kenaf per kilogram adalah Rp.18.000. Total biaya investasi awal adalah 
Rp.893.648.333. Rincian biaya investasi disajikan pada Tabel 3 .

Tabel 3. Biaya investasi

\begin{tabular}{|l|c|r|}
\hline \multicolumn{1}{|c|}{ Komponen } & Jumlah & \multicolumn{1}{c|}{ Biaya (Rp.) } \\
\hline Sewa Lahan & $393(\mathrm{ha})$ & 786.000 .000 \\
\hline Peralatan & & 18.908 .333 \\
\hline Bibit & $4930(\mathrm{~kg})$ & 88.740 .000 \\
\hline \multicolumn{2}{|c|}{ Total Biaya } & 893.648 .333 \\
\hline
\end{tabular}

\section{Biaya Operasional}

Operasional yang dilakukan dalam pemeliharaan tanaman kenaf antara lain pemberian pupuk dan penyemprotan pestisida. Dalam satu kali siklus dibutuhkan pupuk urea sebanyak $500 \mathrm{~kg} / \mathrm{Ha}$ dan pestisida sebanyak 1 liter. Selain pupuk dan pestisida, biaya yang dibutuhkan dalam pemeliharaan sebelum menghasilkan adalah pembayaran tenaga kerja. Upah tenaga kerja dihitung per siklus penanaman. Total biaya operasional sebelum menghasilkan adalah Rp. 2.622.400.000 dengan rincian biaya biaya operasional terdapat pada Tabel 4.

Tabel 4. Biaya operasional sebelum menghasilkan

\begin{tabular}{|l|c|r|}
\hline \multicolumn{1}{|c|}{ Komponen } & Jumlah & \multicolumn{1}{c|}{ Biaya (Rp) } \\
\hline Pupuk Urea & $128.000 \mathrm{Kg}$ & 256.000 .000 \\
\hline Pestisida & 105 liter & 8.400 .000 \\
\hline Tenaga Kerja & & 2.358 .000 .000 \\
\hline \multicolumn{2}{|c|}{ Total Biaya } & 2.622 .400 .000 \\
\hline
\end{tabular}

Biaya operasional yang digunakan setelah menghasilkan adalah biaya untuk proses perendaman, penyeratan, pengeringan, dan pengangkutan. Untuk melakukan proses tersebut dibutuhkan tenaga kerja dan peralatan. Pengangkutan membutuhkan tenaga kerja untuk memindahkan kenaf kering dan mengantarkan ke pengepul. Proses pengiriman ke pengepul menggunakan mobil. Biaya mobil yang dimasukkan ke dalam perhitungan adalah biaya depresiasi per tahun. Biaya bahan bakar yang digunakan pada penelitian ini adalah solar dengan pemakaian satu siklus penanaman sebanyak 960 liter, biaya per liter Rp.9.500. Total biaya setelah menghasilkan adalah Rp 271.120.000. Biaya tenaga kerja disajikan pada Tabel 5.

Dari Tabel 3, Tabel 4, dan Tabel 5 diketahui bahwa total biaya selama satu siklus yaitu $R p$. 6.088.468.333. Jumlah produksi serat kenaf yang dihasilkan untuk $393 \mathrm{Ha}$ adalah 1.179 ton. Harga per $\mathrm{kg}$ serat kenaf adalah Rp. 7.000 , dengan begitu total pendapatan adalah Rp 8.253.000.000. Terdapat selisih yang menjadi laba kotor sebesar Rp 2.164.531.667.

Tabel 5. Biaya operasional setelah menghasilkan

\begin{tabular}{|l|r|}
\hline \multicolumn{1}{|c|}{ Komponen } & \multicolumn{1}{c|}{ Biaya (Rp) } \\
\hline TK Tebang Rendam & 786.000 .000 \\
\hline TK Seset & 1.473 .750 .000 \\
\hline TK Jemur & 294.750 .000 \\
\hline TK Pengangkutan & 3.750 .000 \\
\hline Depresiasi Mobil (per tahun) & 5.050 .000 \\
\hline Bahan Bakar & 9.120 .000 \\
\hline Total Biaya & 2.572 .420 .000 \\
\hline
\end{tabular}

Biaya penggunaan bahan kimia pada tahap pemeliharaan yang berpengaruh besar pada kategori dampak menyumbang $4,2 \%$ dari total biaya keseluruhan. Sedangkan biaya terbesar digunakan untuk membayar tenaga kerja dengan persentase sebesar $80,75 \%$. Biaya tenaga kerja yang begitu besar ini diakibatkan oleh sistem budidaya kenaf yang masih manual sehingga setiap proses sangat tergantung dengan kualitas maupun kuantitas tenaga kerja.

Setelah memperkirakan pendapatan dan pengeluaran maka dilakukan perhitungan NPV, yang menghasilkan nilai Rp. 438.716.959 yang artinya investasi memberikan keuntungan. Perhitungan untuk $\mathrm{B} / \mathrm{C}_{\text {net }}$ menggunakan persamaan 4 maka dihasilan $B / C_{\text {net }}$ sebesar 1,108 .

$$
\mathrm{B} / \mathrm{C}_{n e t}=\frac{R p 4,489,444,889}{R p 4,050,727,930}=1,108
$$

Nilai $\mathrm{B} / \mathrm{C}_{\text {net }}>1$, sehingga dapat dikatakan bahwa proyek layak dilakukan. Perhitungan NPV tersaji pada Tabel 6.

Setelah dilakukan identifikasi biaya dan studi kelayakan berdasarkan NPV dan B/C net, langkah selanjutnya adalah melakukan analisis sensitivitas. Analisis yang dilakukan untuk faktor pertama adalah ketika produksi turun $6 \%$. Biasanya penurunan produksi ini dikarenakan gagal panen di sebagian area yang berasal dari faktor alam. Jika produktivitas lahan turun lebih dari $6 \%$ maka usaha budidaya mengalami kerugian karena NPV bernilai negatif. Perhitungan sensitivitas disajikan pada Tabel 7. 
Tabel 6. Perhitungan NPV

\begin{tabular}{|c|r|c|r|r|r|}
\hline Bulan & Cost (Rp) & Benefit (Rp) & Net benefit (Rp) & DF 0,04 & \multicolumn{1}{c|}{ PV (Rp) } \\
\hline 0 & 874.740 .000 & - & -874.740 .000 & 1,00 & -874.740 .000 \\
\hline 1 & 1.399 .220 .000 & - & -1.399 .220 .000 & 0,96 & -1.345 .403 .846 \\
\hline 2 & 524.480 .000 & - & -524.480 .000 & 0,92 & -484.911 .243 \\
\hline 3 & 524.480 .000 & - & -524.480 .000 & 0,89 & -466.260 .810 \\
\hline 4 & 524.480 .000 & - & -524.480 .000 & 0,85 & -448.327 .702 \\
\hline 5 & 524.480 .000 & - & -524.480 .000 & 0,82 & -431.084 .329 \\
\hline 6 & 2.572 .420 .000 & 8.253 .000 .000 & 5.680 .580 .000 & 0,79 & 4.489 .444 .889 \\
\hline Total & 6.944 .300 .000 & & & & 438.716 .959 \\
\hline
\end{tabular}

Dari keseluruhan penelitian yang telah dilakukan, kekurangan penelitian ini adalah data keuangan yang digunakan masih terbatas pada satu tahun terakhir sehingga apabila terjadi inflasi atau ketidak-pastian lainnya dalam jangka panjang maka studi kelayakan tersebut belum tentu dapat digunakan. Diharapkan penelitian selanjutnya dapat berkembang pada upaya perbaikan untuk mengatasi dampak lingkungan dan analisis keberlangsungan budidaya kenaf dari segi sosial menggunakan metode Social Life Cycle Assessment.

Tabel 7. Analisis sensitivitas

\begin{tabular}{|l|rr|c|}
\hline \multicolumn{1}{|c|}{ Kondisi } & \multicolumn{2}{c|}{ NPV } & B/C net \\
\hline Normal & $\mathrm{Rp}$ & 438.716 .959 & 1,108 \\
\hline Penurunan 6\% & $\mathrm{Rp}$ & 47.369 .012 & 1,01 \\
\hline Penurunan 7\% & $-\mathrm{Rp}$ & 17.855 .646 & 0,99 \\
\hline
\end{tabular}

\section{Kesimpulan}

Hasil LCA dengan metode Eco Indicator 99 dan penilaian single score, menunjukkan bahwa tahap pemeliharaan menjadi penyumbang tertinggi dari tiga kelompok kategori dampak. Urutan tertinggi sampai terendah kelompok kategori dampak yang dipengaruhi oleh tahap pemeliharaan adalah resources dengan nilai $21,4 \mathrm{mPt}$, human health senilai $8,76 \mathrm{mPt}$, dan ecosystem quality senilai $1,91 \mathrm{mPt}$. Pada tahap pemeliharaan terdapat aktivitas penggunaan bahan kimia, yaitu urea dan pestisida. Total biaya dan total pendapatan selama satu siklus penanaman kenaf sampai menghasilkan serat kenaf yaitu Rp. 6.088.468.333 dan Rp 8.253.000.000. Usaha penanaman kenaf sampai diperoleh serat kenaf dapat dilanjutkan karena hasil perhitungan NPV dan $\mathrm{B} / \mathrm{C}_{\text {net }}$ bernilai positif. Hanya saja jika terjadi pengurangan produksi $>6 \%$ maka petani akan mengalami kerugian.
Saran untuk penelitian selanjutnya adalah proses identifikasi biaya dapat dikembangkan dengan menggunakan data historis yang lebih panjang dan melanjutkan penilaian siklus hidup budidaya kenaf secara sosial dengan menggunakan social life cycle assessment.

\section{Daftar Pustaka}

Ahmad, S., Wong, K. Y., \& Ahmad, R. (2019). Life Cycle Assessment for Food Production and Manufacturing: Recent Trends, Global Applications and Future Prospects. Procedia Manufacturing, 34, 49-57.

Akil, H., Zamri, M. H., \& Osman, M. R. (2015). Biofiber Reinforcements in Composite Materials, 138-161. Cambridge: Woodhead Publishing.

Aminah, A., Wong, C. C. \& Hashim, G. M. (2006). Production Potential of Kenaf for Forage and Fibre on BRIS Under Smallholder Production Systems. Fourth Technical Review Meeting on the National Kenaf Research Project. Malaysian Agricultural Research and Development Institute: Malaysia.

Benedict, B. A. (2017). Understanding Full Life-Cycle Sustainability Impacts of Energy Alternatives. Energy Procedia, 107, 309313.

Buyung, R. A. H. F., Pratasis, P. A. K., \& Malingkas, G. Y. (2019). Life Cycle Cost (LCC) Pada Proyek Pembangunan Gedung Akuntansi Universitas Negeri Manado. Jurnal Sipil Statik, 7(11), 1527-1536.

Daddi, T., Nucci, B., \& Iraldo a, F. (2017). Using Life Cycle Assessment (LCA) to Measure The Environmental Benefits of Industrial Symbiosis in an Industrial Cluster of SMEs. Journal of Cleaner Production, 147, 157-164.

Dian, N., Partiwi, S. G., \& Ciptomulyono, U. (2014). Rancangan Perbaikan Proses Produksi Dengan Menggunakan QFD, LCA dan LCC di PT PG Candi Baru, Sidoarjo. Prosiding Seminar Nasional Manajemen Teknologi XXI, 1-10. 
Dreyer, L. C., Niemann, A. L., \& Hauschild, M. Z. (2003). Comparison of Three Different LCIA Methods: EDIP97, CML2001 and Eco-indicator 99. The International Journal of Life Cycle Assessment, 8(4), 191-200.

Frankl, P., \& Rubik, F. (1999). Life-Cycle Assessment (LCA) in Business an Overview on Drivers, Applications, Issues And Future Perspectives. Global Nest: The International Journal, 1(3), 185-194.

Fernando, A. L., Duartea, M. A., Vatsanidou, A., \& Alexopoulou, E. (2015). Environmental Aspects of Fiber Crops Cultivation and Use. Industrial Crops and Products, 68, 105-115.

Goedkoop, M. \& Spriensma, R. (2000) Ecoindicator 99 Manual for Designers. Ministry of Housing, Spatial Planning and the 25 Environment, Den Haag.

Hassan, F., Zulkifli, R., Ghazali, M. J., \& Azhari, C. H. (2017). Kenaf Fiber Composite in Automotive Industry: An Overview. International Journal on Advanced Science Engineering Information Technology, 7(1), 315-321.

Heliyanto, B., Jumali, Sudjindro, \& Sastrosupadi, A. (1998). Respon Berbagai Aksesi Kenaf Terhadap Aluminium Dan Tanah Podsolik Merah Kuning Di Daerah Jorong Kalimantan Selatan. Jurnal Littri, 4(3), 73-78.

Heijungs, R., Guinée, J., Kleijn, R., \& Rovers, V. (2007). Bias in Normalization: Causes, Consequences, Detection and Remedies. The International Journal of Life Cycle Assessment, 12(4), 211-216.

Imfeld, G., \& Vuilleumier, S. (2012). Measuring The Effects of Pesticides on Bacterial Communities in Soil: A Critical Review. European Journal of Soil Biology, 49, 22 30.

Indriani, I., \& Widiawati, D. (2013). Eksplorasi Struktur Serat Tanaman Kenaf (Hibiscus Cannabinus L.) Pasa Teknik Tenun ATBM Sebagai Bahan Baku Tekstil. Jurnal Tingkat Sarjana Bidang Senirupa dan Desain, 1, 18.

Irawati, D. Y., \& Wulandari, L. M. (2019). Life Cycle Assessment Analysis of Kenaf Cultivation in Bonorowo Land, Laren, Lamongan. Jurnal Sistem dan Manajemen Industri, 3(2), 89-97.

ISO 14040. (2006). Environmental management. Life Cycle Assessment: Principle and Framework. International Organisation for Standardization: Geneva, Switzerland.

ISO 14044. (2006). Environmental management. Life Cycle Assessment: Requirements and Guidelines. International Organisation for Standardization: Geneva, Switzerland.
Jeyanthi, S. \& Rani, J.J. (2012). Improving Mechanical Properties by Kenaf Natural Long Fiber Reinforced Composite for Automotive Structures. Journal of Applied Science and Engineering, 15(3), 275-280.

Jonell, M., \& Henriksson, P. J. G. (2015). Mangrove-Shrimp Farms in Vietnam Comparing Organic and Conventional Systems Using Life Cycle Assessment. Aquaculture, 447, 66-75.

Kangiden, D. I., Hartati, R. R. S., \& Marjani. (1996). Penyaringan Galur-Galur Kenaf (Hibiscus Cannabinus L.) Sebagai Penghasil Serat di Lahan Gambut Kalimantan Barat. Prosiding Simposium Pemuliaan Tanaman IV. PERIPI Komda Jatim. UPN Surabaya. $61-66$.

Kardiansyah, T., \& Sugesty, S. (2014). Karakteristik Pulp Kimia Mekanis Dari Kenaf (Hibiscus cannabinus L.) Untuk Kertas Lainer. Jurnal Selulosa, 4(1), 37 46.

Kunzli, N., Perez, L., Rapp, R. (2010). Air Quality and Health. European Respiratory Society: Lausanne, Switzerland.

Li, Y., Zhang, W., Ma, L., Huang, G., Oenema, O., Zhang, F., \& Dou, Z. (2014). An Analysis of China's Fertilizer Policies: Impacts on the Industry, Food Security, and the Environment. Journal of Environmental Quality, 42(4), 972-981.

Marjani, Sudjindro, \& Purwati, R. D. (2009). Daya Hasil Galur-Galur Kenaf di Lahan Podsolik Merah Kuning. Jurnal Littri, 15(2), $53-59$.

Masykur, F. S., \& Puspitasari, C. (2019). Eksplorasi Serat Dan Kain Kenaf Dengan Teknik Tekstil Pada Produk Fesyen. eProceeding of Art \& Design, 6(3), 41024107.

Meiriza, I., Supratman, N. A., \& Tatas, F. (2017). Perancangan Kebijakan Maintenance Mesin Vibro Menggunakan Metode Risk Based Maintenance (RBM) dan Life Cycle Cost (LCC) Di PT Perkebunan Nusantara VIII. E-Proceeding of Engineering, 4(2), 2673-2680.

Miettinen, P., \& Hamalainen, R. P. (1997). How to Benefit from Decision Analysis in Environmental Life Cycle Assessment (LCA). European Journal Of Operational Research, 102, 279-294.

Mohd, H. A. B., Arifin, A., Nasima, J., Hazandy, A. H., \& Khalil, A. (2014). Journey of Kenaf in Malaysia: A Review. Scientific Research and Essays, 9(11), 458-470.

Nemecek, T., Dubois, D., Huguenin-Elie, O., \& Gaillard, G. (2011). Life Cycle Assessment of Swiss Farming Systems: Integrated And Organic Farming. Agricultural Systems, 104(3), 217-232. 
Perez Gil, M., Contreras Moya, A. M., \& Domínguez, R. E. (2013). Life Cycle Assessment of The Cogeneration Processes in The Cuban Sugar Industry. Journal of Cleaner Production, 41, 222-231.

Petrillo, A., De Felice, F., Jannelli, E., Autorino, C., Minutillo, M., \& Lavadera, A. L. (2016). Life Cycle Assessment (LCA) and Life Cycle Cost (LCC) Analysis Model for A Stand-Alone Hybrid Renewable Energy System. Renewable Energy, 95, 337-355.

Purnomo, E., Mursyid, A., Syarwani, M., Jumberi, A., Hashidoko, Y., Hasegawa, T., Honma, S., \& Osaki, M. (2005). Phosporus Solubilizing Microorganism in The Rhyzhosphere of Local Rice Varities Grown Without Fertilizer on Acid Sulphate Soils. Soil Science \& Plant Nutrition, 51(5), 679-681.

Santoso, B. (2014). Teknik Budi Daya Varietas Baru Kenaf Di Lahan Bonorowo, Podsolik Merah Kuning, Dan Gambut. Balai Penelitian Tanaman Tembakau dan Serat: Malang.

Santoso, B., Jamil, A. H., \& Machfud, M. (2015). Manfaat Kenaf (Hibiscus cannabinus L.) Dalam Penyerapan Karbondioksida (CO2). Perspektif, 14(2), $125-133$.

Sastrosupadi, A. \& Santoso, B. (2002). Pengaruh Pupuk Makro dan Mikro di Lahan Gambut Kalimantan Tengah. Laporan Hasil Penelitian. Balittas: Malang.

Singh, J., Kunhikrishnan, A., Bolan, N.S., \& Saggar. S. (2013). Impact of Urease Inhibitor on Ammonia and Nitrous Oxide Emissions from Temperate Pasture Soil Cores Receiving Urea Fertilizer and Cattle Urine. Science of The Total Environment, $465,56-63$.
Sudjindro. (2012). Inovasi Varietas Unggul Kenaf Untuk Pemberdayaan Lahan Sub Optimal Di Indonesia. Orasi Pengukuhan Profesor Riset Bidang Pemuliaan dan Genetika Tanaman. Jakarta: IAARD Press.

Tahir, P. M., Ahmed, B. A., Saiful Azry, S. O. A., \& Ahmed, Z. (2011). Retting Process of Some Bast Plant Fibers and Its Effect on Fiber Quality: A Review. Bio Resources, 6(4), 5260-5281.

Tukker, A. (2000). Life Cycle Assessment as a Tool in Environmental Impact Assessment. Environmental Impact Assessment Review, 20, 435-456.

Tuomisto, H. L., Hodge, I. D., Riordan, P., \& Macdonald, D.W. (2012). Does Organic Farming Reduce Environmental Impacts? A Meta-Analysis of European Research. Journal of Environmental Management, 112, 309-320.

Utari, M., Yasmini, \& Edwina, S. (2016). Analisis Kelayakan Finansial Usaha Perkebunan Karet Program EKS UPP TCSDP di Desa Bina Baru Kecamatan Kampar Kiri Tengah Kab. Kampar. Jurnal Online Mahasiswa Fakultas Pertanian Universitas Riau, 3(2), 99-102.

Vinka, E. T. H., Ra'bagob, K. R., Glassnerb, D. A., \& Gruberb, P. R. (2003). Applications of Life Cycle Assessment to NatureWorksTM Polylactide (PLA) Production. Polymer Degradation and Stability, 80, 403-419.

Wang, P., Wang, J., Qin, Q., \& Wang, H. (2017). Life Cycle Assessment of Magnetized Fly-Ash Compound Fertilizer Production: A Case Study in China. Renewable and Sustainable Energy Reviews, 73, 706-713. 